\title{
On the Relationship of Peer-Review Training and Writing Proficiency among Iranian EFL Learners
}

\author{
Reza Raissi \\ Universiti Teknologi Malaysia, Malaysia \\ raissi_reza@yahoo.com
}

\begin{abstract}
Nowadays most of the scholars in the field of foreign/second language learning emphasized on the role of peer-reviewing and students' feedback to each other's work in writing composition. In many educational systems different educational reformations have been happened and many educational systems in the field of foreign/second language teaching changed the English teaching methods from old language teachings like Audio-lingual Method (ALM) and Grammar Translation Method (GTM) to modern language teaching methods like Task Based Language Teaching (TBLT) and Communicative Language Teaching (CLT). In CLT approach it has been emphasized that students should work with each other in group or pair work and the role of the teacher is as a facilitator or coachin order to push the students to discuss and challenge in the classroom; that walks around the class and gives feedback to the students' works. In this study researcher used a quasi-experimental research design in which he had two different groups namely experimental and control groups. Students at the experimental group received peer-review writing instruction and feedback while students in the control group did not. Results of the study showed that peer-review of students can increase students' writing proficiency to a high extent. At the end of the study some pedagogical implications have been suggested by the researcher which can help researchers in this field.
\end{abstract}

Keywords: Peer-reviewing, writing proficiency, CLT, EFL

\section{Introduction}

Previously English language instructors in the ESL/EFL field applied oral language skills, taught grammar and vocabulary in English writing classes which has been changed during the recent years. According to Matsuda, (2003) during the recent decade different researchers did different kinds of the study in the field of writing, which changed this field of enquiry to the interdisciplinary field of research. Kushner (2003) emphasized the importance of the writing in the global village as an essential need for the students; in which different people all around the world have to communicate with each other in English as lingua franca by sending emails, chatting or sending different documents to each other. So it seems the importance of writing skill and writing instruction in the field of foreign/second language gained equal importance to speaking, as students, scholars, and people all around the world need writing proficiency ability in order to communicate with each other easily for different purposes such as studying abroad, writing articles, emails, etc. According to Halliday (2003) it seems very vital for English language learners to have a good command of written language in order to be successful for at least economical purposes in $21^{\text {st }}$ century, as they need to communicate with their foreigner partners through global networks. In the same vein Juzwik, et al (2006) emphasized on the fact that general demand of writing proficiency has significant importance in social and political issues. Different people have different English needs in their life in order to convey their meaning by written language, such as communicating in the net, social networks, sending emails, or other online documentations. They are supposed to have good command of writing proficiency especially when they want to convey their meaning in political era.

By considering these points in mind, researcher investigated the role of modern language teaching approaches like Communicative Language Teaching (CLT), and Task Based Language Teaching (TBLT), on the students' writing proficiency performance. In some new and common language teaching approaches especially in CLT approach the role and importance of peer-reviewing has been emphasized to a high extent. Mainly in the language classes the role of the teacher is as a coach or facilitator in which he/she nominates the students to work two by two or in different groups and by giving feedback to each other students can 
improve their writing ability. In these situations mainly teacher uses student's feedback to each other and as a coach walks around the class to help them to be improved in writing. Therefore the results of the current study seem important in the field of second/foreign language studies. As students and teachers can benefit the results of the current study to know whether peer-workings in writing can improve their writing capacity or not, furthermore curriculum designers can benefit from the results to revise their offering curriculum in a way which can push the students to be more proficient in writing.

\section{Literature review}

According to Taylor \& Wigglesworth (2009) Communicate Language Teaching (CLT) approach is beneficial and effective in writing instruction in both learning and assessment contexts in which this approach actively uses receptive and productive language skills of the students by pushing them to work with each other during the class activities and giving feedback to each other during peer and group works. Storch (2007) mentioned when English language learners are engaged in group and pair works in writing they will achieve linguistic gains during this procedure. He emphasized on the fact that by increasing the amount of pair assessment in the EFL/ESL contexts for testing L2 writing ability of the students, learners can incorporate their interaction skills and accordingly they can improve both reading and speaking skills during peer-reviewing challenges. Wigglesworth \&Storch (2009) conducted a study to compare university L2 writers working individually and who were working in pairs. Results of the study showed that working in pair and peer-reviewing had significant positive impact on the students' accuracy while it didn't affect their fluency and grammatical competence of the learners. Satio \& Fujita (2009) mentioned English language instructors should pay special attention when they want to evaluate group works and group cooperation. Most of the times it seems difficult to make clear that in the group and pair works which member did better and making the amount of the cooperation of each member in the group work for the teachers are problematic. Satio\& Fujita (2009) offered two ways of assessing group members' cooperation in group works namely inter-group peer-assessment and intra-group peer-assessment. In Inter-group peer-assessment students judge the quality of other groups member cooperation with each other and they will report the cooperation percentage of each member to the instructor while in intra-group assessment each group member evaluates the amount of the other group members' contribution to his/her learning outcome. Another shortcoming of the peer-review writing instruction is that there is no evidence to support the assumption that learners with high cooperation produced higher quality in individual essays or better written assignments. McCombs (1997) classified different kind of students' assessment of the peer-reviewing works namely formative assessment, selfassessment, peer-response, and reflective portfolio, in which students can monitor and assess their progress and reflect their inner voice. He mentioned that self-assessment, peer-response and processes of reflection are pedagogical tools that help instructors to know EFL/ESL teachers know their students' perception and ideas regarding second/foreign language writing, knowing students' personal characteristics and it leads teachers to teach in a way he/she can motivate students to perform better.

\section{Methodology}

Research design: In this study researcher used quasi-experimental research design in which he had 14 weeks of class instruction to two different groups of students, namely experimental group and control group. Students in the experimental group received peer-review writing instruction while students in the control group didn't receive any treatment in peer-review writing. At the beginning and end of semester two composition tests (pre \& post-tests) were ran from both experimental \& control groups, and the results of the tests were compared descriptively to see the differences between the mean of the scores who received peerreview instruction in writing and who didn't. Additionally pre \& post-test feedback questionnaire were distributed among experimental group to know their opinion regarding the peer-review writing.

Participants: The participants of the study were 60 undergraduate EFL instructors in Islamic Azad University (IAU), Tehran, Iran. Their level of English proficiency were intermediate and their age rang was 19 to 43. All of them studied English as a compulsory subject and 23 of them were male while 37 were female. 30 of them received treatment in the experimental group while 30 of them didn't receive treatment in the control group. 


\section{Research questions}

- Does peer-reviewing affect students' writing proficiency in composition?

- Does incorporating peer-reviewing in writing affect students' perceptions regarding the effectiveness of this method in EFL classes?

\section{Data analysis \& discussion}

In this section result of the study presented. Results of the study consists of two main sections, the first section relates to the analysis of the pre \& post-test writing composition scores which relates to both experimental and control groups and the second section relates to pre \& post-test of peer-feedback questionnaire which relates to experimental group. In the first section results of the writing composition test which has been administrated for both groups at the beginning and end of the academic semester have been presented.

Results of the writing composition test (Experimental group) Descriptive statistics of the writing composition scores. In order to see whether peer-reviewing procedure affected student's performance in the experimental group, descriptive statistics was ran which has been presented in this section.

Table 1: Descriptive statistics of the pre \& post-test of the experimental group

\begin{tabular}{llllll}
\hline & N & Minimum & Maximum & Mean & Std. Deviation \\
\hline pretest & 30 & 40.00 & 91.00 & 56.4000 & 15.12614 \\
posttest & 30 & 40.00 & 90.00 & 76.3667 & 14.74960 \\
Valid N (list wise) & 30 & & & & \\
\hline
\end{tabular}

As it seems clear from the above table the mean of the composition essay writing scores has been increased between pre-test \& post-test(from 56 to 76 out of 100) which proves that peer-reviewing process of writing and group works in the writing classes have been improved students' composition writing to a high extent. Paired sample t-test between pre \& post-test of composition writing scores in the experimental group In order to make comparison between the pretest and posttest of writing composition scores, paired matched t-test was ran which has been presented in this section.

Table 2: Paired sample t-test between pre \& post-test of writing composition scores (experimental group)

\begin{tabular}{|c|c|c|c|c|c|c|c|c|}
\hline & \multicolumn{5}{|c|}{ Paired Differences } & \multirow{3}{*}{$\begin{array}{c}\mathbf{t} \\
\mathrm{e} \\
\mathrm{e}\end{array}$} & \multirow[t]{3}{*}{ df } & \multirow{3}{*}{$\begin{array}{ll}\text { Sig. } & (2- \\
\text { tailed) }\end{array}$} \\
\hline & Mean & $\begin{array}{l}\text { Std. } \\
\text { Deviation }\end{array}$ & $\begin{array}{l}\text { Std. E } \\
\text { Mean }\end{array}$ & $\begin{array}{l}\text { Error95\% } \\
\text { Interval } \\
\text { Difference }\end{array}$ & $\begin{array}{l}\text { Confidence } \\
\text { of the }\end{array}$ & & & \\
\hline & & & & Lower & Upper & & & \\
\hline $\begin{array}{ll}\text { Pair } 1 & \begin{array}{l}\text { pretest } \\
\text { posttest }\end{array} \\
\end{array}$ & -- 19.96667 & 21.92854 & 4.00359 & -28.15492 & -11.77841 & -4.987 & 29 & .000 \\
\hline
\end{tabular}

As it seems clear from the above table there is a significant difference between the results of the writing composition scores between the pretest and posttest which proves this fact that writing proficiency of the students has been improved during the course instruction of writing peer-reviewing significantly.

Results of the writing composition test (Control group) Descriptive statistics of the composition scores: In order to see whether writing composition ability of the students has been improved without peer-reviewing process, descriptive statics of the pretest and posttest of the control group ran which has been presented in the following section.

Table 3: Descriptive statistics of the composition writing scores pre \& post-test (control group)

\begin{tabular}{llllll}
\hline & N & Minimum & Maximum & Mean & Std. Deviation \\
\hline pretest & 30 & 38.00 & 90.00 & 51.4000 & 11.20222 \\
posttest & 30 & 40.00 & 85.00 & 54.6667 & 11.52010 \\
Valid N (list wise) & 30 & & & & \\
\hline
\end{tabular}


As it is crystal clear from the above table, the mean of the scores haven't been changed significantly from the pretest to the posttest (the mean of the scores in the pretest was 51 while it became 54 out of 100 in the posttest), results of the control group proves the fact that by using old language teaching methods like Grammar Translation Method (GTM), writing ability of the students wouldn't increase to a high extent.

Paired sample t-test between pre \& post-test of composition writing scores in the control group: A comparison between the pre \& post-tests of the composition writing course has been done by paired sample t-test in this study which is presented in this section.

Table 4: Paired sample t-test of the pre \& post-test of composition writing scores (control group)

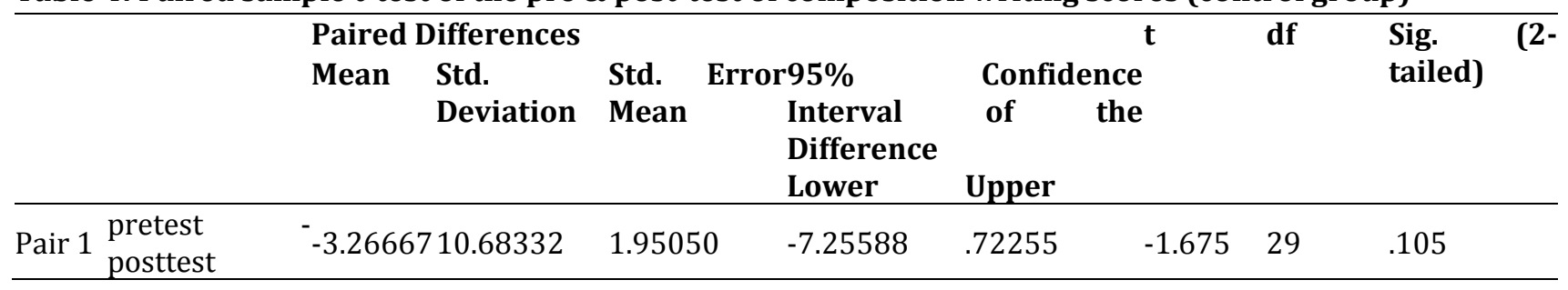

As it has been shown in the above table there was not a significant difference between pre \& posttests in the control group which proves the fact that by incorporating old language teaching approaches like GTM, instructors cannot help the students to improve their writing ability and it seems that using peer-reviewing and group work can help students to perform better in their writing tasks.

Comparison of pre \& post-test perceptions of the EFL Learners regarding peer-feed back: Before conducting the experiment researcher distributes peer-feedback questionnaire (questionnaire extracted from the net and the validity of the questionnaire approved by 5 experienced EFL instructors), and after the experiment the same questionnaire distributed among them in order to extract students' opinions before and after the treatment. In this section descriptive statistic regarding each item has been discussed in detail, questionnaire had 7 criteria, and students nominated to choose one option for each criteria. They had to choose one out of the following options, not useful at all, a little useful, useful and very useful. Questionnaires' criteria were: 1. Peer-feedback \& comments are useful or not, 2. Reading and commenting on my peer essays are useful or not, 3. Teachers feedback is necessary or not, 4. Students prefer to receive only teachers' feedback, 5. Students prefer to receive only peer's feedback, 6. Students prefer teachers and students feedback, 7. I don't prefer to receive any feedback.

Students' perceptions regarding peer-feedback Results of the study regarding peer-review feedback perceptions (pretest of experimental group): In this section the results of the study regarding peer-feedback has been provided by descriptive statistics, to this aim results of the pre and posttests has been presented by the researcher. Results of the students' perceptions regarding the peer-feedback (pre-test)

Table 5: Descriptive statistics regarding students' perceptions of peer-review trainings in writing (pretest of experimental group)

\begin{tabular}{llllll}
\hline & $\mathbf{N}$ & Minimum & Maximum & Mean & Std. Deviation \\
\hline Usefulness of peer-feedback & 30 & 1.00 & 4.00 & 2.0000 & 1.00000 \\
Reading own work & 30 & 1.00 & 4.00 & 2.1724 & .88918 \\
Teacher feedback & 30 & 1.00 & 4.00 & 1.9655 & .94426 \\
Only peer-feedback & 30 & 1.00 & 4.00 & 2.1724 & .88918 \\
Teacher and peer-feedback & 30 & 1.00 & 4.00 & 2.1724 & 1.00246 \\
No feedback & 30 & 1.00 & 4.00 & 2.0690 & .92316 \\
Valid N (list wise) & 30 & & & & \\
\hline
\end{tabular}

As it seems clear from the above table the mean of the scores in most items were around 2 which means they believed all the mentioned factors regarding the peer-review in writing composition is a little useful from their view points before starting the experiment by the researcher.

Results of the study regarding peer-review feedback perceptions (posttest of experimental group) 
Table 6: Descriptive statistics regarding students' perceptions of peer-review trainings in writing (pretest of experimental group)

\begin{tabular}{llllll}
\hline \multicolumn{1}{l}{} & $\mathbf{N}$ & Minimum & Maximum & Mean & Std. Deviation \\
\hline Usefulness of peer-feedback & 30 & 2.00 & 4.00 & 2.9667 & .80872 \\
Reading own work & 30 & 2.00 & 4.00 & 3.2000 & .76112 \\
Teacher feedback & 30 & 2.00 & 4.00 & 3.1667 & .79148 \\
Only peer-feedback & 30 & 2.00 & 4.00 & 2.9000 & .88474 \\
Teacher and peer-feedback & 30 & 1.00 & 4.00 & 3.0000 & .94686 \\
No feedback & 30 & 2.00 & 4.00 & 3.1333 & .89955 \\
Valid N (list wise) & 30 & & & & \\
\hline
\end{tabular}

As it seems clear from the above table most of the mean scores about all factors are around 3, which means useful, when we compare the results to the pretest we can conclude that their perceptions regarding peerfeedback increased to a high extent and changed a little useful to useful.

\section{Conclusion \& Pedagogical implications}

As it has been discussed earlier in the findings section it seems very essential to focus on peer work \& peerfeedback in essay writing classes, the results of this experiment revealed this fact that Communicative Language Teaching (CLT) \& Task Based Language Teaching (TBLT) approaches help the students to improve their writing ability to a high extent. As it has been mentioned in the results the mean of scores of the writing composition course have been increased in the experimental group between the pretest and posttest which means experiment was useful enough to push the students write. When students give feedback to each other the role of the teacher is as a coach or facilitator who can help students in order to avoid errors to be fossilized in the learners' mind. On the other hand results of the students' perceptions about peer-feedback which have collected from the students reveals that after course instruction in the experimental group students had more positive attitudes regarding writing in groups and their attitudes regarding group works has been increased positively to a high extent. Hopefully the results of the current study is useful for a number of people who can benefit from the results namely teachers who can benefit the results of the study in their instruction, students to benefit the results to practice writing with their partners in a perfect way and curriculum designers and administrative executives to use the results of the current study in revising curriculums in a beneficial way for the students' pedagogical purposes.

\section{References}

Halliday, M. A. K. (2003). Written language, standard language, global language. World Englishes, 22(4) 405418.

Juzwik, M. M., Curcic, S., Wolbers, K., Moxley, K. D., Dimling, L. M. \& Shankland, R. K. (2006). Writing into the 21st century: An overview of research on writing, 1999 to 2004. Written Communication, 23, 451476.

Kushner, E. (2003). English as global language: Problems, dangers, opportunities. Diogenes, 50(2), 17-23.

Matsuda, P. K. (2003). Second language writing in the twentieth century: A situated historical perspective. In Exploring the Dynamics of Second Language Writing B. Kroll (Ed.) (pp. 15-34). New York, NY: Cambridge University Press.

McCombs, B. L. (1997). Self-assessment and reflection: Tools for promoting teacher changes toward learnercentered practices. NASSP Bulletin, 81, 1-14.

Saito, H. \& Fujita, T. (2009).Peer-assessing peers' contribution to EFL group presentations. RELC Journal, $40(2), 149-171$.

Storch, N. (2007). Investigating the merits of pair work on a text editing task in ESL classes. Language Teaching Research, 11(2), 143-159.

Taylor, L. \& Wigglesworth, G. (2009). Are two heads better than one: Pair works in L2assessment contexts? Language Testing, 26(3), 325-339.

Wigglesworth, G. \& Storch, N. (2009). Pair versus individual writing: Effects on fluency, complexity and accuracy. Language Testing, 26(3), 445-466. 